Article received on March $1^{\text {st }} 2019$

Article accepted on May $16^{\text {th }} 2019$

UDC: $78.036(44)$

$78.036(497.11)$

\author{
Miloš Bralović* \\ Serbian Academy of Sciences and Arts \\ Institute of Musicology
}

\title{
ANNULLING THE TRAUMA: NEOCLASSICISM AS A MODERNIST (?) ANTIDOTE TO SOCIETY'S ILLS ${ }^{1}$
}

\begin{abstract}
In this paper, we shall examine the overall conditions of the emergence of neoclassicism in Paris, shortly after the First World War. Compared to that, the emergence of neoclassicism in Serbian music is also going to be examined having in mind that neoclassicism, as a dominant movement, appears in Serbian music significantly later - after the Second World War. At this point, the only correlation between the two neoclassicisms is that they both appear after the significant, primarily destructive historical events. What would their other similarities and differences be?
\end{abstract}

Keywords: Neoclassicism, Paris 1920s, Belgrade 1950s, moderated modernism, First World War, Second World War.

\section{Emotions in a can}

While going through one of the (in the terms of the digital age, old) dictionaries, one might find this definition:

NEOCLASSICISM (new classicism), a movement, which appeared during the years which followed the First World War as a reaction to late romanticism (with its offspring, expressionism) and impressionism. Its emergence is in many ways conditioned by the crisis of the spiritual life which was a consequence of wartime and societal events. [...] New anti-romantic aesthetics, so-called new objectivity

* Author contact information: milosbralovic@gmail.com

1 This paper was written as a part of the project Identities of Serbian Music from Local to Global Frames: Traditions, Changes, Challenges (No. 177004), financed by the Ministry of Education, Science and Technological Development of the Republic of Serbia. 
(from the Ger.[man] term Neue Sachlichkeit) assumed a sober, abstained, 'Apollonian' art, in which the old ideal would be resurrected: balance between form and content, objectivisation of emotions, solid formal construction. Conducting these principles to their final consequences sometimes leads to postulates of formalist aesthetics, which considers music as a game of sounds and annuls its emotional content. ${ }^{2}$

This definition contains several crucial points which are going to be discussed in this paper. One of them would be the emergence of neoclassicism as a compositional practice and as a term which assumes it, historical (but also geographical) contexts in which neoclassicism appears, including its aesthetical postulates and mentioned contexts which conditioned those postulates.

Dragutin Gostuški argues that in the history of art and music there is

a certain psychological explanation of positive changes: in the initial stadium of a style a basic model is established, which completely satisfies the current situation: time, and, the increasingly expanded use of standard methods gradually diminish the influence of the basic models to the observers; because of that one incessantly strives towards the new, primarily morphologically more complex way of expression; but in the final stadium of the process, even extreme solutions lose their transcendent force. At that point, as the only way out, the need appears towards a return to the basic, simple models; but with that type of leap, in itself, one achieves that complex emotional effect which was strived for, embodied in a shock. ${ }^{3}$

2 ["NEOKLASICIZAM (novoklasicizam), smer koji se u godinama neposredno posle Prvog svetskog rata pojavio kao reakcija na pozni romantizam (sa njegovim izdankom ekspresionizmom) i impresionizam. Njegov nastanak je u mnogome uslovljen krizom duhovnog života prouzrokovanom ratnim i društvenim zbivanjima. [...] Nova antiromantična estetika, tzv. Nova objektivnost (od nem.[ačkog] termina Neue Sachlichkeit), zastupa treznu, uzdržanu, 'apolinijsku' umetnost, u kojoj bi vaskrsli klasični ideali: uravnoteženost forme i sadržaja, objektivizacija emocija, čvrsta formalna konstrukcija. Sprovođenje tih načela do krajnjih konsekvenci vodi katkad do pozicija formalističke estetike, koja smatra muziku igrom zvukova i odriče joj emocionalni sadržaj."] (Engl. transl. by the author.) Vlastimir Peričić, "Neoklasicizam" ["Neoclassicism”] u: Krešimir Kovačević (ur.), Muzička enciklopedija [Musical Encyclopedia], Zagreb, Jugoslovenski leksikografski zavod, 1974, 670.

3 [“...izvesno psihološko objašnjenje pozitivnih promena: u početnom stadiju stila ustanovljava se osnovni model koji potpuno zadovoljava datu situaciju: vreme i sve proširenija upotreba standarnih metoda postepeno umanjuju dejstvo prvobitnih tipova na posmatrača; zbog toga se neprestano teži novom, prvenstveno morfološki kompleksnijem načinu izražavanja; ali u krajnjem stadiju procesa čak i ekstremna rešenja gube svoju transcedentnu snagu. Tada se kao jedini izlaz, javlja potreba za povratkom na početne, 
This, as it appears, psychological explanation of a permanent return towards the classical is further emphasised in this way: "That is where the sense of relief, consciousness of the sublimity of the moment and passionate, often even careless activity of building a future world come from - all of that which characterizes periods of European classicism. Contrary to that the man of the Baroque era lives, above all, in the present". ${ }^{4}$ Finally, Gostuški claims that every change of stances happens in one of two alternative ways - evolution and reaction, where

The other phenomenon [reaction] appeared three times so far in the new history of Europe. At the beginning of Romanesque art, the humanism of the Renaissance and with the classicism of the $18^{\text {th }}$ century. [...] historical moments marked (among other things) by the return towards the classical forms were always, at the same time periods of the biggest upheavals, the most fateful deviations of European action programmes by all points in politics, economics, philosophy, science, in the way of life and in relation to it. ${ }^{5}$

Although Gostuški does not mention $20^{\text {th }}$ century Neoclassicism in the quoted paragraph, it is not difficult to assume (in comparison with the first definition) that the "leap" from complex to simple solutions, the "careless activity of building a future world", or the phenomenon of reaction, are some of the features that also apply to it, as one of many others, in the broadest sense of that word, classicist tendencies throughout history. However, in both Peričićs definition and Gostuški's arguments regarding the appearance of the classical, it is implied that neoclassicism and/or classical tendencies in the broader sense appear after major changes, even conflicts in politics, economics, society, resulting in both collective and individual trauma.

jednostavne modele; ali samim tim skokom ostvaruje se u vidu šoka onaj snažni emocionalni efekt za kojim se težilo."] (Engl. transl. by the author.) Dragutin Gostuški, Vreme umetnosti, [The Time of Art], Beograd, Prosveta, 1968, 133.

4 ["Odatle ono osećanje olakšanja, svest o uzvišenosti trenutka i strasna, često čak i bezobzirna aktivnost da se izgradi jedan budući svet - sve ono dakle što karakteriše periode evropskog klasicizma. Suprotno tome, čovek baroknih perioda živi pre svega u sadašnjici“.] (Engl. transl. by the author.) Ibid.

5 ["Ovaj drugi fenomen [reakcija] pojavio se do sada tri puta u novoj istoriji Evrope. U početku romanskog doba, sa humanizmom Renesanse i sa klasicizmom 18. veka. [...] istorijski momenti obeleženi (između ostalog) povratkom klasičnim oblicima bili su uvek istovremeno i periodi najvećih potresa, najsudbonosnijih devijacija ackionog programa Evrope u svim tačkama, u politici, privredi, filozofiji, nauci, umetnosti, u načinu života i u odnosu prema njemu“.] (Engl. transl. by the author.) Ibid. 
Regarding the term "trauma", it "comes from the Greek $\tau \rho \alpha \tilde{v} \mu \alpha$, meaning 'wound. This term mostly refers either to physical injury caused by external force or to a type of psychological damage that occurs as a result of a severely distressing event". 6 While even laymen may assume music may help people deal with their mental trauma (whatever the cause of it), the relationship between traumatic events and the overall development of culture and arts seems to have a slightly different course. For example, while discussing several of Alfred Schnittke's (1934-1998) late operas, Ivana Medić notes that in them

Schnittke employs narrative strategies that can be regarded as a response to trauma. Namely traumatised characters have fairly limited access to reliable conscious memories (and therefore the truth) of an event. As a result, they see symptoms of trauma [...] as literal re-experiences of trauma and history as unassimilable into a linear narrative. In his operas Schnittke employs flashbacks, broken narration, surreal episodes, keeping the viewer constantly in doubt as to whether what we are seeing on stage is 'real' or not.'

There are, of course, numerous other examples of dealing with trauma and trauma in general in various stage works through history, ${ }^{8}$ and this was to illustrate one of the possible ways of noting and interpreting them in a group of works of a certain author. But, what happens if/when trauma changes everything, in colossal proportions?

\section{What can one do with emotions in a can? (1)}

At the turn of the century in France, according to Scott Messing, there were various terms that in different ways denoted art and music, which were connected to any sort of past traditions. Therefore, in the late 1800 s, the term neo-

\footnotetext{
6 Ivana Medić, "Alfred Schnittke's Operas from the 1990s in the Context of Trauma Studies”, in: Sonja Marinković et al. (eds.), Challenges in Contemporary Musicology, Belgrade, Faculty of Music, 2018, 248.

7 Ibid., 253-254. It is worth noting that the author deals with three of Schnittke's operas: Life with an Idiot (1990-1992), The History of Dr Johann Faust (1984-1994) and Gesualdo (1993), with specific postmodernist features, influenced by the postmodern context (although their plots are not related to the time in which the operas were created), and events such as the fall of The Berlin Wall (1989), the dissolution of The Soviet Union (1991), etc.

8 There are numerous examples of various trauma in opera, from, for example, Gaetano Donizzeti's (1797-1848) Lucia di Lammermoor, to Alban Berg's (1885-1935) Wozzek and many others.
} 
classicism (néoclassicisme, in literature), "especially that represented by the art of late eighteenth-century France, was distinctly out of favor. [...It] had a generally pejorative undertone arising from the disdain for what some late nineteenth-century writers considered a colorless imitation of Greek and Roman art and a servile captivation with academic niceties." ${ }^{9}$ Later on, Messing adds:

The term neoclassicism with regard to music occurs with increasing frequency only after 1900 . These references suffice to give neoclassicism a specific definition during the first decade of the twentieth century: an expression pertaining to nineteenth-century composers, who perpetuated the forms of instrumental music made popular during the eighteenth century, but who sacrificed originality and depth of musical substance to the abject imitation of structure. ${ }^{10}$

As Messing argues, the derogatory meaning persisted in music as in literature, except in music, the term neoclassicism "aggravated by nationalist feelings, since [neoclassicism] was invariably used [...] by French writers to describe German musicians". ${ }^{11}$ Contrary to this term, at the turn of the century, following various nationalist tendencies in France, the term new classicism (nouveau classicisme) was used to denote French music based on the revival of French music of past times, as opposed to German music of the time. ${ }^{12}$ Or, as Jane Fulcher (while discussing the period of the First World War, and elements of nationalism in French cultural politics) would put it, Opéra and other cultural institutions served

as a realm of national memory and myth, to install a unified wartime identity in a politically and culturally fractured France. Here the myth was that of French classicism: France was 'Latin' and thus classic in culture, but according to a circumscribed notion of the style that was rooted in the ideology of the monarchist Right. ${ }^{13}$

9 Scott Messing, Neoclassicism in Music. From the Genesis of the Concept through the Schoenberg/Stravinsky Polemic, Rochester, University of Rochester Press, 1996, 13.

${ }^{10}$ Ibid., 13-14.

${ }^{11}$ Ibid., 14.

${ }^{12}$ Cf. Ibid., 24. Here Messing refers to various pieces written by Léo Delibes (18361891), Camille Saint-Saëns (1835-1921), Maurice Ravel (1875-1937), Vincent d'Indy (1851-1931), Claude Debussy (1862-1918) and others, who used, for example, dance idioms and other conventions of $17^{\text {th }}$ and $18^{\text {th }}$ century (French) music.

${ }_{13}$ Jane F. Fulcher, The Composer as Intellectual. Music and Ideology in France, 1914-1940, Oxford, Oxford University Press, 2006, 20. Fulcher argues that during the First World War and in the following decade, composers belonging to the conservative Right in France (followers of César Franck [1822-1890] or Camille Saint-Saëns, such as, for ex- 
Leaving the political division to Left and Right in early $20^{\text {th }}$ century France aside at this moment, one comes to the conclusion that the mentioned terminology (at least when it comes to music) primarily served to describe, on the one hand, German music - and its potentially negative influence on French music - with the term neoclassicism, and on the other, to denote everything related to French tradition, which is rooted in classical Latin culture, thus represented as a 'good role model' for the composers whose works (once they were written) were dubbed with the term new classicism.

Following the end of the First World War, a change in the meaning of the terms occurred:

Some propagandists of contemporary art tended to disavow any kinship with pre-war styles, which, with few exceptions, they generally regarded as corrupt in one way or another. For these artists and critics, Debussy was the avatar of impressionism [...]. Likewise, Ravel was associated with a gaudy romanticism and the fact that La valse was his first post-war work encouraged this assessment. ${ }^{14}$

For example, one of those propagandists was Jean Cocteau (1889-1963), who praised Erik Satie (1866-1925): “Cocteau set Satie apart from either pre-war trends or remote national traditions. The 'classical' path of clarity which Cocteau accorded Satie was a solitary one that did not reach into the past. The 'new simplicity' of Satie [...] was both 'classic' and 'modern'; 'a French mu-

ample, Vincent d'Indy) advocated the rhetoric by which French culture was in its foundation Latin (not Greek), therefore classical, in contrast with 'Nordic' romanticism and the irrationalism of the 'Huns', Cf. Jane F. Fulcher, “The Composer as an Intellectual: Ideological Inscriptions in French Interwar Neoclassicism”, The Journal of Musicology, Vol. 17, No. 2, University of California Press, 1999, 200. This rhetoric led to the formation of the "League pour la Défence de la Musique Française" by Charles Teronc in 1916, with the aim of keeping French music pure and free from any other 'unwanted' influences namely those of contemporary German and Austrian music (although the music of Viennese $18^{\text {th }}$ century classicism was considered a good role model) - which was reflected in the opera and concert repertoire of the time. Cf. Ibid., 203-204. Meanwhile, composers (and/as intellectuals) connected to the Left (such as, to various extents, Maurice Ravel, Erik Satie or "Les Six") considered the classic models to be something more of a universal model, non-related to race or nationality, where the works they produced were marked as both 'traditional' and 'modern'. Cf. Ibid., 211-212. There are different 'alignments' of the mentioned composers, regarding their relations to the Right and Left (such as in the case of Maurice Ravel, for example), which is going to be put aside at this point. Also, the use of popular music and contemporary everyday life topics was important to Left-aligned composers, but that aspect could be elaborated as a different topic.

14 Scott Messing, op. cit., 76. 
sic' that did not recall any other French music". ${ }^{15}$ Therefore, Satie's music, in Cocteau could be accounted for as modernist. These, in the broadest sense, modernist features of neoclassicism (in its new, post-war meaning) were, according to Messing, the artists' tendency towards

stabilizing reentry into the mainstream of European art and a nostalgia for the past which that return implied. Contemporary to that tendency [...] an alliance with the past might compromise creativity and it was wise to remain a cultural orphan. [....] The term [neoclassicism] enjoyed a renewed life beginning in 1923 because it was associated with Stravinsky, [...] and that relationship would prove decisive in securing a meaning for neoclassicism that was different from what it once had. ${ }^{16}$

So far, various mentioned authors who tackled the different aspects, in the broadest sense, of (neo)classical aesthetics, have mentioned or indirectly implied that the situation, regarding the notion of the term, its implied aesthetics or cultural politics in general, changed in the years following the end of the First World War. The reasons for that change are to be found at both the collective and individual level, as either psychological, sociological, economical, etc. But before examining various details regarding the aesthetics of neoclassicism and the poetics of certain authors, one should examine a different context of the emergence of neoclassicism.

Leaving aside other European countries where neoclassicism appeared (such as the Weimar Republic, the Soviet Union or Italy), we are going to speak about several conditions in which neoclassicism in Serbian music appeared, bearing in mind not only its geographical but also temporal distance.

Neoclassicism emerged relatively late in Serbian music, compared to its French counterpart. It appeared in the 1950s as a dominant movement, embodied within so-called moderate modernist tendencies. In the meantime another war of colossal proportions occurred (and that was the Second World War), and the Yugoslav state polity and the societal system changed (a monarchy in the interwar period, Yugoslavia became a federal republic led by the Communist party). This influenced several changes in the arts and culture, especially if one has in mind that during the 1930s, “...the return of, at the time, the youngest generation of composers who had studied abroad, members of the 'Prague Group' [which] was marked in local history as the

$\begin{array}{ll}15 & \text { Ibid., } 77 . \\ 16 & \text { Ibid., } 85 .\end{array}$ 
first avant-garde wave in Serbian music..., ${ }^{17}$ although there were several modest neoclassical contributions before the Second World War, embodied in, for example, the works of Predrag Milošević (1904-1988, a member of the 'Prague group'). ${ }^{18}$ After the Second World War, "a simplified aspect of musical neoclassicism in Serbia, recognisable by the premises of socialist realism, was, in fact, a consequence of [its] ideological and political use". ${ }^{19}$ These premises of socialist realism were somewhat present in the "turnabout towards the method of realism" 20 in the late 1930s, but, according to Mirjana Veselinović-Hofman,

the thesis of socialist realism had never been manifested in its most dogmatic way [...]. An open confrontation between the political establishment of our country and the Soviet Union, made public in June 1948, significantly contributed to that. [....] Although the new political situation in post-war Yugoslavia made possible even the abandonment of socialist realism in theory, artistic production was, up to 1951, and even 1954, even in Serbia, subordinated to various aspects of ideological or political control. ${ }^{21}$

And as socialist realism started to fade throughout the 1950s, "the only possible modernistic challenge that Serbian artists could make in relation to the

17 [“...da bi povratak sa studija kompozitora tada najmlađe generacije, pripadnika 'praške grupe', koji domaća istorija beleži kao 'prvi avangardni' udar u srpskoj muzici..."]. (Engl. transl. by the author). Vesna Mikić, Lica srpske muzike: neoklasicizam [Faces of Serbian Music: Neoclassicism], Beograd, Fakultet muzičke umetnsoti, 2009, 106.

18 Cf. Ibid., 107.

19 [“Симйлификовани виg музичког неокласицизма у Србији, препознатљив по премисама социјалистичког реализма, био је, у ствари, последица [његове] идеолошке и политичке употребе“.] (Engl. transl. by the author). Мирјана ВеселиновићХофман, "Музика у другој половини XX века" ["Music in the Second Half of the $20^{\text {th }}$ Century”], у: Мирјана Веселиновић-Хофман (ур.), Истиорија срйске музике. Срйска музика и евройско наслеђе [History of Serbian Music. Serbian Music and European Heritage], Београд, Завод за уџбенике, 2007, 108.

20 [“заокрета ка методи реализма“]. (Engl. transl. by author). Ibid.

21 [“соцреалистичка теза се у српској музици није испољила у свом најекстремнијем догматском виду [...]. Томе је знатно допринео отворени сукоб тадашњег политичког врха наше земље и Совјетског Савеза, обзнањен крајем јуна 1948, [....] иако су нове политичке прилике у тадашњој Југославији учиниле теоретски могућим чак и напуштање соцреалистичких позиција, уметничко стваралаштво је све до 1951. па и до 1954. године и у Србији било изложено разним видовима идеолошко-политичке контроле“"]. (Engl. transl. by the author). Ibid., 108-109. 
culture and its 'prescribed' aesthetic norms was moderate modernism". ${ }^{22}$ Also, moderate modernism, as the author explains, denotes non-radical modernism "as a kind of 'umbrella' term of the Serbian music of the 1950s. This kind of approach could, possibly, in our opinion: [...] facilitate the understanding of very complicated neo/ism terminology..... 23 The reasons for the temporal distance of some 30 years which appeared between Serbian neoclassicism and its French counterpart are to be sought in the modern history of Serbian music (in terms of fine arts), which was developing in different historical, socio-political conditions, thus being 'in delay' with an artistic canon which was yet to be confirmed and upgraded, rather than criticised, subverted, or deconstructed, which was the case in European $20^{\text {th }}$ century art and culture. ${ }^{24}$

So far, the notion of the emergence of neoclassicist French or Serbian/ Yugoslav content has been the topic of this discussion, throughout the genesis of the term, the points in history in which neoclassicism emerged and the mention of some of its basic features. Further on, we are going to delve deeper into the aesthetic features of neoclassicism and examine two 'products' of neoclassicist poietics.

\section{What can one do with emotions in a can? (2)}

Theodor Adorno, while discussing Stravinsky's music, claimed that its restoration features were in correspondence with the regression of the society. ${ }^{25}$ Stravinsky tried to reconcile the music of the $18^{\text {th }}$ century and modern music, by using the old compositional techniques and (at first) subordinating the contemporary ones to them, thus creating a dissonance between the old and the new. ${ }^{26}$ This dissonance, then, became Stravinsky's individual compo-

22 Vesna Mikić, "Aspects of (Moderate) Modernism in the Serbian Music of the 1950s", in: Dejan Despić, Melita Milin (eds.), Rethinking Musical Modernism, Belgrade, Institute of Musicology, Serbian Academy of Science and Arts, 2008, 187-188.

23 Ibid., 187. The term moderate modernism could be used in broader contexts. The definition of moderate modernism is a broad subject concerning the transformed results of the avant-garde into a mass consumerist art. This represents a different topic, and for the purposes of this paper, moderate modernism is going to be used as an 'umbrella' term of various neo/isms.

24 For more information, see: Vesna Mikić, Neoklasicizam... op. cit., 105-111.

25 Cf. Theodor W. Adorno, Filozofija nove muzike [Philosophy of New Music], (transl. by Ivan Focht), Beograd, Nolit, 1968, 219.

26 Ibid., 222. 
sitional idiom. ${ }^{27}$ When applied to the neoclassical movement, it is not hard to conclude that Adorno's attitude towards it was negative in the sense that neoclassicism, (according to its main features, in terms of the socio-historical contexts of the time) was anti-modern. In that manner, for Makis Solomos, 'call to order', which Cocteau proclaimed in 1923, stigmatised the modernity of fauvism, expressionism, cubism and constructivism. ${ }^{28}$

Leaving this viewpoint aside, there were numerous claims whereby a return of some sort which implied a method which could be named a 'healing procedure. In France, as we have mentioned earlier, it was the balance between nostalgia for the past and modernity, it was a 'middle path' that was proclaimed by Cocteau. In Germany, it was Johann Sebastian Bach's (16851750) music. ${ }^{29}$ And apparently, various 'healing procedures' were a part of the "careless activity of building a future world", mentioned in the introduction of this paper. In whichever way these tendencies were interpreted by the contemporaries or more or less distant successors, the 'healing procedures' were, apparently, a part of the project of modernity, clearly a looking-forward feature of modernism. ${ }^{30}$ And if we add Daniel Albright's claim that modernism is "the testing of the limits of aesthetic construction", ${ }^{31}$ modernism becomes a significantly broader concept. In that regard, Albright adds, "Modernism was a movement associated with the scrupulous choice of artistic materials, and with hard work in arranging them. Sometimes the Modernists deflected the domain of artistic selection to unusual states of consciousness (trance, dream, and so forth); but, except for a few dadaist experiments, they didn't abandon

27 Ibid.

${ }^{28}$ Cf. Makis Solomos, "Néoclassicisme et postmodernisme: deux antimodernismes", in: Musurgia, Vol 5, No. 3/4, 1998, 92, https://www.jstor.org/stable/40591798, ac. 22. 02. 2019.

29 For more information see: Walter Frisch, "Bach, Regeneration and Historicist Modernism“ in: German Modernism. Music and the Arts, Berkeley, Los Angeles, London, University of California Press, 2005, 138-185. This tendency led to the appearance of "historicist modernism", a movement embodied in the works of Ferruccio Busoni (18661924) and Max Reger (1873-1916), which Walter Frisch claims to be different from neoclassicism, unlike Scott Messing, who, while discussing music at the turn of the century in Germany, sees the same tendencies as, in broadest sense, neoclassical, see: Scott Messing, „Neoclassicism in Germany“, in: op. cit., 61-74.

30 Cf. Miško Šuvaković, "Modernizam“, u: Miško Šuvaković, Pojmovnik teorije umetnosti [Lexicon of Art Theory] Beograd, Orion Art, 2012, 448.

31 Daniel Albright, Untwisting the Serpent. Modernism in Music, Literature and other Arts, Chicago and London, The University of Chicago Press, 2000, 29. 
artistic selection entirely.... ${ }^{32}$ With this claim, one could imagine how neoclassicism could be accounted for as modernism.

Although not written by a French composer by origin, Igor Stravinsky's works of the interwar period became crucial for defining neoclassical aesthetics, according to Scott Messing's research. In that manner, are there any 'healing' aspects of Stravinsky's music? Or, how does Stravinsky create a bridge between tradition and modern, which was an appropriate gesture of a 1920s composer in Paris? "Stravinsky claimed that he was not pretending to write the music of the future [...] when he argued that 'Modernists have ruined modern music' during an interview in New York in 1925...."33 And the solution to what was called "ruined modern music" could be found in this composer's claim: "my liberty will, in the same manner, be greater and deeper if I narrowly restrain my field of action and surround myself with as many obstacles as possible. That thing that removes obstacles also removes force". ${ }^{34}$ Therefore, the key is self-restraint in composing, which complements Albright's claims on modernism. Therefore we shall look at several features of the ballet Apollo (1928).

The simplicity of this ballet is visible in its scoring. Stravinsky decided to use a rather reduced string orchestra with a total of 34 players as it is noted in the score. Therefore, with the use of a monochromatic ensemble, from the beginning, any 'unexpected' change of timbre is avoided, thus annulling any possible surprise to the ears of the listeners. This is supported by the fact that Stravinsky avoids any 'sudden movements', such as abrupt changes in the dynamic or techniques such as col legno. Maybe the most striking features, with regard to Stravinsky's self-made composing obstacles, are melody and rhythm. Rhythm features in the ballet are relatively static and the least prone to change. In relation to that, any change of meter is to allow the 'more natural' forward movement or flow of the melody. Compared to the rhythm, the melodic features are, as it seems, the most prone to change. Nevertheless, their change is strictly controlled through the process of permanent varying, therefore, any change in melodic material is always prepared, or it is always gradual. The

\footnotetext{
32 Ibid., 31.

33 Maurin A. Carr, After the Rite. Stravinsky's Path to Neoclassicism (1914-1925), Oxford - New York, Oxford University Press, 2014, 31.

34 ["moja sloboda biće utoliko veća i dublja ukoliko uže ograničim svoje polje akcije i okružim se sa više prepreka. Ono što mi uklanja smetnju, otklanja mi snagu“.] (Engl. transl. by author). Igor Stravinski, Moje shvatanje muzike [My Understanding of Music], Beograd, Vuk Karadžić, 1966, 27.
} 
musical language is mostly diatonic, with rather rare bitonal chord constructions. All of these compositional procedures are in many ways related to Stravinsky's concept of composing according to the principle of similarity, found in the composer's interpretation of chrononomy and derived from Pierre Suvchinsky's theory of ontological and psychological time. ${ }^{35}$ Everything is in accordance with a Greek mythology inspired plot, focused on Apollo and the three muses, Terpsichore, Polyhymnia and Calliope. Thus, Stravinsky 'cures' modern music by limiting himself to compositional procedures which are or can be perceived as classical, yet following his own expression, embodied in the previously cited statement about the composer's poetics. ${ }^{36}$

Switching to a different context as we did in the previous chapter, we are going to discuss a piece by one of the most prominent Belgrade based neoclassical composers in the period after the Second World War. Milan Ristic (1908-1982) was inaugurated as a neoclassical composer when, after a short break in the years which followed the Second World War, the composer returned to the Belgrade music scene with his Second Symphony (1951). Nevertheless, during the occupation of Yugoslavia, the war inspired works appeared in Ristićs opus. This thematic is obvious in the works such as the First Symphony (1941), or symphonic poem Man and War (Čovek i rat, 1943). According to Marija Bergamo

Ristić started working on the [First] Symphony only four days after Hitler's attack on USSR. During five months of intensive work, some sort of personal reaction to outside events, the composer made a piece of strained dynamics, rich in sounding, which, in thick, polyphonic lines grows up to distraught cries, startling weeping and heroic accents. ${ }^{37}$

35 For more information see: Igor Stravinski, op. cit., 16-18; Мирјана ВеселиновићХофман, Преg музичким gелом, [Towards the Work of Music], Београд, Завод за уџбенике, 2007, 127-128.

36 It is worth to note that Stravinsky, throughout his so-called neoclassical period, tended to restore the compositional procedures of the past he was inspired with. This is more obvious in his works which contain cited material, where the material implies compositional procedures which are to be used. Cf. Mirjana Veselinoivć-Hofman, Fragmenti o muzičkoj postmoderni [Fragments on Musical Postmodernity], Novi Sad, Matica srpska, 1997, 45-46.

37 ["Ristić je započeo rad na [Prvoj] simfoniji samo četiri dana posle Hitlerovog napada na SSSR. U toku pet meseci intenzivnog rada, nekoj vrsti lične reakcije na spoljašnje događaje, stvorio je delo napregnute dinamike, zasićeno u zvuku koji u gustim, polifonim linijama narasta do izbezumljenih krikova, potresnih vapaja i herojskih akcenata".] (Engl. transl. by author). Marija Bergamo, Delo kompozitora. Stvaralački put Milana Ristića od 
In this, like author named it, mature expressionist period, where the most significant work is the First Symphony, the composer tries to "compromise between technique and expression of Schoenberg and Hindemith." 38 Above all, the author refers to consistency in applying Arnold Schoenberg's (1874-1951) "principle of atonality", but never dogmatically understood and used dodecaphony, which are contrasted Paul Hindemith's (1895-1963) principles of compositional techniques, regarding the motivic work, while at the same time, in Ristićs opus exist a strong foundation embodied in classical forms and polyphony. ${ }^{39}$

It is understandable that after the Second World War, and a changed socio-political situation in the country, Ristić, during the mentioned short break in his opus, and while socialist realism dominated in cultural politics, from time to time wrote several socially engaged works, such as various arrangements of folksongs and even a few melodrams. It seems that, at that time, a need for establishing stable foundations appeared, not only in the poietics of Milan Ristić or his contemporaries but also in the total cultural life of Belgrade after 1945. In words of Bergamo, "There came a new period of contradictions and crisis, filled with wandering and fluctuating, which were gradually turned into the new, more correct movements and stronger impulses which were affirmed after 1950" 40 Those new, more correct movements and stronger impulses are referring to the mentioned neoclassicist tendencies in Ristićs works created during the sixth decade of the $20^{\text {th }}$ century.

Having decided to commit himself to composing symphonic music (although he was very prolific in other genres), in 1957 the composer wrote Symphonic Variations. ${ }^{41}$ By following the principles obvious in the poietics

Prve do Šeste simfonije, [Opus of a Composer. Creative Development of Milan Ristić from the First to the Sixth Symphony], Beograd, Univerzitet umetnosti, 1977, 43.

38 [“izvrši kompromis između tehnike i izraza Schönberga i Hindemitha”.] (Engl. transl. by author). Ibid., 40.

39 Cf. Ibid., 40-41.

40 ["Nastupio je novi period protivrečnosti i krize, ispunjen lutanjima i kolebanjima, koja su postepeno pretvarana u nova, pravilnija talasanja i čvršće impulse koji su se afirmisali posle 1950."] (Engl. transl. by author). Ibid., 63.

41 Milan Ristić, among his other colleagues (namely Ljubica Marić, [1909-2003] and Stanojlo Rajičić [1910-2000]), after the early, radical modernist phase of the 1930s and later, having been faced with the doctrine of socialist realism after 1945, dedicated himself towards establishing moderate modernist tendencies in Serbian music throughout the 1950s, by dismissing the proclaimed ideals of socialist realism (which never be- 
of Paul Hindemith (1895-1963), of which some were elaborated in Hindemith's last lecture entitled "Dying Waters" in 1963, Milan Ristić explored the boundaries and tried to surpass (to use the term related to Stravinsky) the obstacles of neoclassicism. Namely, Hindemith argued that a non-modal system of "total tonality", that is, expanded tonality which uses all twelve tones of the chromatic scale, represents one of the most suitable systems for music creation. ${ }^{42}$ That is the musical language employed in Ristićs Variations, scored for a symphonic orchestra $a$ due. The theme in the form of a threephrase period, centred around B-flat, already contains all twelve tones of the chromatic scale. Through nine variations (the last of which is a fugue), the composer exploits all the potential of the theme, thus creating and presenting its (sometimes completely different) 'faces' to the audience. While acknowledging all the principles of the development variation (as established by Arnold Schoenberg [1874-1951] and his successors), Ristić retains the integrity of the theme, which, like any other theme used for variations, could fall apart into separately varied fragments. Therefore, this feature of the rather short piece for orchestra becomes the most important in the neoclassicist restoring of "primary stylistic features" of classical variations. ${ }^{43}$

\section{Conclusion}

The purpose of this paper was not to show the direct implications of war trauma in the lives of the composers (or people in general), or to examine all the socio-political changes influenced by the war in relation to culture and the arts, but to examine in which way the composers and music critics

\footnotetext{
came an official doctrine of cultural politics in Yugoslavia). For more informations see: Весна Микић “Неокласичне тенденције“, ["Neoclassical tendencies"], у: Мирјана Веселиновић-Хофман (ур.), Истиорија срйске... ор. cit., 193-213; Vesna Mikić, Lica srpske... op. cit.

${ }^{42}$ Cf. Paul Hindemith, "Umiruće vode“ ["Dying Waters"], (transl. by Marija Koren), in: Vlastimir Peričić et al. (ed.), Zvuk. Jugoslovenska muzička revija, No. 69, 1966, 453-454. For Hindemith, every system in which the composer seeks novelty in organising the tone material, such as the twelve-tone technique, is not truly innovative. It is also worth noting that Hindemith claimed this at the time when composers such as Karlheinz Stockhausen (1928-2007), John Cage (1912-1992), Krzysztof Penderecki (b. 1933) and other representative composers of various avant-garde movements were active.

43 On neoclassicist restoring of "primary stylistic features" see: Mirjana VeselinovićHofman, Fragmenti... op. cit., 30.
} 
sought stability in various aspects of culture, the arts and individual poietics. Starting from the genesis of the term, or more precisely, the definition of neoclassicism and the neoclassical through history, had obviously undergone changes. The meaning changed according to the different ways of (im)possible restorations or revivals of the musical past(s) and the different ways of their interpretation. On the one hand it is possible to apply the methodology of defining a style to map the features of neoclassicism (but also of any other movement of the first half of the $20^{\text {th }}$ century such as, for example, expressionism), and on the other (more suitable) hand, bearing in mind that we are defining an artistic movement, neoclassicism is defined and understood under the 'cover' of moderate modernism. Keeping in mind its features, one could debate whether or not neoclassicism is modernism. And before, or instead of a conclusion on this subject, one could offer a three-part formula, for understanding the matrix of neoclassicism.

Looking towards the (musical) past (or not any past, but the one that became a tradition) in order to regain stability in any field (possibly after a collective war trauma), from individual poietics to the music scene, could be the first part. This is a common feature of various neoclassical composers despite the fact that in their different opera the composers sought a way of revitalizing it or demonstrating that it is impossible to revitalize it. The second part would concern the mentioned process of restoring primary stylistic features, or, introducing a tradition into a contemporary context. ${ }^{44}$ The third part would then become a combination of the previous two. As every tradition contains its own rules, those rules become the features of restraint in the composers' poietics. Despite that, those restraints become the field in which the neoclassicist composer demonstrates his/her compositional skill. In other words, music for Gostuški's careless creation of the future world becomes - whether the composers of that time agreed with the 'music for the future' aspect "or not" - innovation in restraint.

44 For more information see: Miško Šuvaković, op. cit., 449. 


\section{Works cited}

Adorno, Theodor W.: Filozofija nove muzike [Philosophy of New Music], (transl. by Ivan Focht). Beograd.: Nolit, 1968.

Albright, Daniel: Untwisting the Serpent. Modernism in Music, Literature and other Arts. Chicago and London: The University of Chicago Press, 2000.

Carr, Maurin A.: After the Rite. Stravinsky's Path to Neoclassicism (1914-1925). Oxford New York: Oxford University Press, 2014.

Frisch, Walter: "Bach, Regeneration and Historicist Modernism" in: German Modernism. Music and the Arts. Berkeley - Los Angeles: London, University of California Press, 2005, 138-185.

Fulcher, Jane F.: “The Composer as an Intellectual: Ideological Inscriptions in French Interwar Neoclassicism”, The Journal of Musicology, Vol. 17, No. 2, 1999, 197-230.

Fulcher, Jane F.: The Composer as an Intellectual. Music and Ideology in France, 1914-1940. Oxford: Oxford University Press, 2006.

Gostuški, Dragutin: Vreme umetnosti [The Time of Art]. Beograd: Prosveta, 1968.

Hindemith, Paul: "Umiruće vode" ["Dying Waters"'], (transl. by Marija Koren), in: Vlastimir Peričić et al. (ed.), Zvuk. Jugoslovenska muzička revija, 69, 1966, 455-458.

Kovačević, Krešimir (ed.): Muzička enciklopedija [Musical Encyclopedia]. Zagreb: Jugoslovenski leksikografski zavod, 1974.

Medić, Ivana: "Alfred Schnittke's Operas from the 1990s in the Context of Trauma Studies", in: Sonja Marinković et al. (eds.), Challenges in Contemporary Musicology. Belgrade: Faculty of Music, 2018, 247-259.

Messing, Scott: Neoclassicism in Music. From the Genesis of the Concept through the Schoenberg/Stravinsky Polemic. Rochester: University of Rochester Press, 1996.

Mikić, Vesna: "Aspects of (Moderate) Modernism in the Serbian Music of the 1950s", in: Dejan Despić, Melita Milin (eds.), Rethinking Musical Modernism. Belgrade: Institute of Musicology, Serbian Academy of Sciences and Arts, 2008, 187-193.

Mikić, Vesna: Lica srpske muzike: neoklasicizam. Beograd: Fakultet muzičke umetnosti, 2009.

Solomos, Makis: "Néoclassicisme et postmodernisme : deux antimodernismes", in: $\mathrm{Mu}$ surgia, Vol 5, No. 3/4, 1998, 91-107, https://www.jstor.org/stable/40591798, ac. 22.02.2019.

Stravinski, Igor: Moje shvatanje muzike [My Understanding of Music]. Beograd: Vuk Karadžić, 1966.

Šuvaković, Miško: Pojmovnik teorije umetnosti [Lexicon of Art Theory]. Beograd: Orion Art, 2012.

Veselinović-Hofman, Mirjana: Fragmenti o muzičkoj postmoderni [Fragments on Musical Postmodernity], Novi Sad: Matica srpska, 1997,

Веселиновић-Хофман, Мирјана: “Музика у другој половини XX века” [“Music in the Second Half of the 20 th Century”], in: Мирјана Веселиновић-Хофман (ed.), Истиорија срйске музике. Срйска музика и евройско наслеђе [History of Serbian 
Music. Serbian Music and European Heritage. Београд: Завод за уџбенике, 2007, 107-135.

Веселиновић-Хофман, Мирјана: Преg музичким gелом, [Towards the Work of Music]. Београд: Завод за уџбенике, 2007.

Микић, Весна: “Неокласичне тенденције“ [“Neoclassical tendencies”], in: Мирјана Веселиновић-Хофман (еd.), Истиорија срйске музике. Срйска музика и евройско наслеђе. Београд: Завод за уџбенике, 2007, 193-213.

\section{Summary}

The First World War ended a hundred years ago. This historical event of colossal proportions significantly changed both European and world history. And it is very probable that in the following years (that is, the 1920s), this event influenced many 'calls to order', to paraphrase the title of Jean Cocteau's infamous 1923 essay. Therefore, in this paper, we first examined (in the most general terms) overall historical conditions which influenced the emergence of neoclassicism in Paris, before and shortly after The Great War. With this in mind, we also examined the overall conditions of the emergence of neoclassicism in Serbian music, which (acknowledging several modest attempts before The Second World War) appeared as a (sort of) dominant movement significantly later, compared to its French counterpart, that is, in the 1950s. At this point, the only correlation between the two neoclassicisms is that they both appear after significant, primarily destructive, historical events. Therefore, having in mind that after two wars of vast proportions, contexts changed, we examined the ways by which the composers (that is Igor Stravinsky and Milan Ristić, as case studies) tried to find a stable way into mainstream art and, to some extent, redevelop their poietics. 
Чланак примљен 1. марта 2019.

Чланак прихваћен 16. маја 2019.

\section{Милош Браловић*}

Српска академија наука и уметности

Музиколошки институт

\section{НЕУТРАЛИЗОВАЊЕ ТРАУМЕ: НЕОКЛАСИЦИЗАМ КАО МОДЕРНИСТИЧКИ (?) ПРОТИВОТРОВ ЗА ДРУШТВЕНЕ БОЉКЕ1}

Апстракт: У овом раду, представићемо услове у којима се неокласицизам појавио у Паризу, убрзо након завршетка Првог светског рата. Исто тако, представићемо и услове у којима се неокласицизам појављује у српској музици, будући да се ту, као доминантан правац, у поређењу са својим француским панданом појављује знатно касније - након Другог светског рата. У овом тренутку, једина корелација између два неокласицизма је да се и један и други појављују након значајних, али примарно деструктивних историјских догађаја. Које би потом биле друге сличности и разлике између њих?

Кључне речи: неокласицизам, Париз двадесетих, Београд педесетих, умерени модернизам, Први светски рат, Други светски рат

\section{Спутане емоције}

Прелиставајући неки од (у терминима дигиталног доба старих) речника, можемо пронаћи следећу дефиницију:

НЕОКЛАСИЦИЗАМ (новокласицизам), смер који се у годинама непосредно после Првог светског рата појавио као реакција на позни романтизам (са његовим изданком експресионизмом) и импресионизам. Његов настанак је у многоме условљен кризом духовног живота проузрокованом ратним и друштвеним збивањима. [...] Нова антиромантична естетика, тзв. Нова објективност (од нем.[ачког] термина Neue Sachlichkeit), заступа трезну, уздржану, 'аполинијску' уметност, у којој би васкрсли класични идеали: уравнотеженост форме и садржаја, објективизација емоција, чврста формална конструкција. Спровођење тих начела до крајњих консеквенци води каткад до позиција формалистичке естетике, која сматра музику игром звукова и одриче јој емоционални садржај. ${ }^{2}$

Драгутин Гостушки тврди да у историји уметности и музике постоји

извесно психолошко објашњење позитивних промена: у почетном стадију стила установљава се основни модел који потпуно задовољава дату ситуацију: време и

\footnotetext{
${ }^{1}$ Овај рад је настао у оквиру пројекта Идентитети српске музике од локалних до глобалних оквира: традиичје, промене, изазови (бр. 177004), који финансира Министарство просвете, науке и технолошког развоја Републике Србије.

${ }^{2}$ Vlastimir Peričić, „Neoklasicizam“, u: Krešimir Kovačević (ur.), Muzička enciklopedija, Zagreb, Jugoslovenski leksikografski zavod, 1974, 670.
} 
све проширенија употреба стандарних метода постепено умањују дејство првобитних типова на посматрача; због тога се непрестано тежи новом, првенствено морфолошки комплекснијем начину изражавања; али у крајњем стадију процеса чак и екстремна решења губе своју трансцедентну снагу. Тада се као једини излаз, јавља потреба за повратком на почетне, једноставне моделе; али самим тим скоком остварује се у виду шока онај снажни емоџионални ефект за којим се тежило. ${ }^{3}$

Ово, чини се, психолошко објашњење сталног повратка класичним узорима објашњава се даље на следећи начин: „Одатле оно осећање олакшања, свест о узвишености тренутка и страсна, често чак и безобзирна активност да се изгради један будући свет све оно дакле што карактерише периоде европског Класицизма. Супротно томе, човек барокних периода живи пре свега у садашњици“. ${ }^{4}$ Коначно, Гостушки заступа тврдњу према којој се свака промена убеђења или норми и ставова дешава на један од два могућа начина - еволуција или реакција где:

Овај други феномен [реакција] појавио се до сада три пута у новој историји Европе. У почетку романског доба, са хуманизмом Ренесансе и са класицизмом 18. века. [...] историјски моменти обележени (између осталог) повратком класичним облицима били су увек истовремено и периоди највећих потреса, најсудбоноснијих девијација ацкионог програма Европе у свим тачкама, у политици, привреди, филозофији, науци, уметности, у начину живота и у односу према њему. ${ }^{5}$

Иако Гостушки не спомиње неокласицизам XX века у цитираним одломцима, није тешко претпоставити (уколико имамо у виду и прву дефиницију) да „скок“ од сложених ка једноставнијим решењима, „безобзирна активност да се изгради један будући свет“, или феномен реакције јесу неке од одлика које се односе и на неокласицитам, као једну од бројних класицистичких тенденција у најширем смислу те речи. Међутим, и Перичић и Гостушки у својм дефиницијама тренутка појављивања класичног имплицирају да се неокласицизам и/или класицистичке тенденције у ширем смислу јављају након великих промена, често и политичких, економских или друштвених конфилкта, што истовремено резултира индивидуалним и колективним траумама.

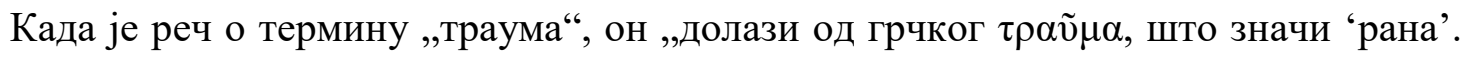
Овај термин се најчешће односи на физичку повреду изазвану спољном силом или ментално оштећење које се дешава након веома узнемиравајућег догађаја“. 6 Чак и лаици могу да претпоставе да музика може да помогне људима у превазилажењу менталних траума (који год да је њихов узрок), али, чини се да је однос између трауматичних догађаја и укупног развоја културе и уметности изграђен на нешто другачији начин. На пример, Ивана Медић примећује да

\footnotetext{
${ }^{3}$ Dragutin Gostuški, Vreme umetnosti, Beograd, Prosveta, 1968, 133.

${ }^{4}$ Ibid.

5 Ibid.

${ }^{6}$ [“"comes from the Greek $\tau \rho \alpha \tilde{v} \mu \alpha$, meaning 'wound'. This term mostly refers either to physical injury caused by external force or to a type of psychological damage that occurs as a result of a severely distressing event."]. (Прев. аутор). Ivana Medić, "Alfred Schnittke's Operas from the 1990s in the Context of Trauma Studies”, in Sonja Marinković et al. (Eds.), Challenges in Contemporary Musicology, Belgrade, Faculty of Music, $2018,248$.
} 
Шнитке [Alfred Schnittke] користи наративне стратегије које изгледају као одговори на трауме. Наиме, трауматизовани ликови ограничено приступају својим свесним сећањима (самим тим и истини) о неком догађају. Као резултат тога, они виде симптоме трауме [...] као њено дословно проживљавање и историју коју није могуће склопити у линеарни наратив. У својим операма, Шнитке користи ретроспекцију, изломљену нарацију, надреалне епизоде, држећи гледаоца константно под сумњом у смислу да никада нисмо сигурни да ли је оно што видимо на сцени 'стварно' или не.

Наравно, постоје бројни други примери суочавања са траумом и трауме уопште у различитим сценским делима у историји музике, ${ }^{8}$ а овај пример је послужио као илустрација једног могућег начина на који се оне могу приметити и интерпретирати у одређеним делима одабраног аутора. Али, шта се дешава ако/када траума промени све у огромним размерама?

\section{Шта учинити са спутаним емоцијама? (1)}

Како наводи Скот Месинг (Scott Messing), на прелому векова, у Француској су постојали различити термини којима су се описивале уметност и музика повезане са било којом прошлом традицијом. Према томе, крајем XIX века, термин неокласицизам (néoclassicisme, у књижевности), „нарочито онај који се везивао за француску уметност са краја XVIII века, није био пожељан. Имао је негативан подтекст, који би настајао из онога што су неки писци са краја XIX века сматрали безбојном имитацијом грчке или римске уметности уз верно дочаравање академских лепота“. 9 Даље, Месинг додаје:

У вези са музиком, термин неокласицизам се појављује чешће тек након 1900. године. Ове помени су довољне да одреде значење термина неокласицизам током прве декаде XX века: израз коришћен за композиторе XIX века који су неговали музичке форме инструменталне музике XVIII века, али који су жртвовали оригиналност и дубину музичке супстанце зарад бедне имитације структуре. ${ }^{10}$

\footnotetext{
${ }^{7}$ [,,Schnittke employs narrative strategies that can be regarded as a response to trauma. Namely traumatised characters have fairly limited access to reliable conscious memories (and therefore the truth) of an event. As a result, they see symptoms of trauma [...] as literal re-experiences of trauma and history as unassimilable into a linear narrative. In his operas Schnittke employs flashbacks, broken narration, surreal episodes, keeping the viewer constantly in doubt as to whether what we are seeing on stage is 'real' or not."]. (Прев. аутор). Ibid., 253-254. Уочавамо да се ауторка бави трима операма: Живот са идиотом (1990-1992), Историја доктора Јохана Фауста (1984-1994) и Безуалдо (1993), које имају специфичне постмодернистичке одлике формиране у постмодерном контексту (иако се радње самих опера не одвијају у времену у којем су настале) и догађајима као што су пад Белинског зида (1989) или распад Совјетског Савеза (1991) и тако даље.

${ }^{8}$ Постоје бројни примери различитих траума у опери, као у операма Лучија од Ламермура (Lucia di Lamermoor) Гаетана Доницетија (Gaetano Donizzeti, 1797-1848) или Воцек (Wozzeck) Албана Берга (Alban Berg 1885-1935) и многих других.

${ }^{9}$ [,,especially that represented by the art of late eighteenth-century France, was distinctly out of favor. [...It] had a generally pejorative undertone arising from the disdain for what some late nineteenth-century writers considered a colorless imitation of Greek and Roman art and a servile captivation with academic niceties."]. (Прев. аутор). Scott Messing, Neoclassicism in Music. From the Genesis of the Concept through the Schoenberg/Stravinsky Polemic, Rochester, University of Rochester Press, 1996, 13.

${ }^{10}$ [,,The term neoclassicism with regard to music occurs with increasing frequency only after 1900 . These references suffice to give neoclassicism a specific definition during the first decade of the twentieth century: an expression pertaining to nineteenth-century composers who perpetuated the forms of instrumental music made popular during the eighteenth century, but who sacrificed originality and depth of musical substance for the abject imitation of structure.’]. (Прев. аутор). Ibid., 13-14.
} 
Према Месингу, негативно значење термина је опстало у музици као и у књижевности, с тим што је у музици, термин неокласицизам „био поткрепљен националистичким осећањима, будући да су га, без изузетка користили [...] француски писци да означе немачке музичаре“. ${ }^{11}$ Супротно овом термину, на прелому векова, у складу са различитим националистичким тенденцијама у Француској, термин нови класицизам (nouveau classicisme) коришћен jе да означи француску музику засновану на оживљавању француске музичке прошлости, наспрам савремене немачке музике. ${ }^{12}$ Или, према Џејн Фалчер (Jane Fulcher, која разматра период Првог светског рата и елементе национализма у културној политици Француске), опера је (као и друге институције културе) служила „као простор за креирање националне меморије и мита, да постави јединствени ратни идентитет у политички и културно разједињеној Француској. Мит се овде односи на француски класицизам: Француска је латинска' и, према томе, класична култура, на основу стилских одлика које су прописивали представници монархистичке деснице“. ${ }^{13}$ Остављајући по страни политичку поделу на лево и десно у Француској са почетка XX века, долазимо до закључка да је поменута терминологија (барем када је у питању музика) са једне стране, примарно служила да опише немачку музику - и њен могући негативан утицај на француску музику - помоћу термина неокласицизам, а са друге стране, да означи све што је повезано са француском традицијом и укорењено у латинској култури и, услед тога, представљано као 'добар узор' за композиторе чија су дела (онда када би настала) била означена термином нови класицизам.

11 [“was aggravated by nationalist feelings, since [neoclassicism] was invariably used [...] by French writers to
describe German musicians.”]. (Prev. autor). Ibid., 14.
${ }^{12}$ Cf. ibid. Овде Месинг мисли на различите комаде које су компоновали Лео Делиб (Léo Delibes, 1836-
1891), Камиј Сен Санс (Camille Saint-Saёns, 1835-1921), Морис Равел (Maurice Ravel, 1875-1937),
Винсент Денди (Vincent d'Indy, 1851-1931), Клод Дебиси (Claude Debussy, 1862-1918) и други,
користећи, на пример, одлике стилизованих игара и других конвенција (француске) музике XVII и XVIII
века. ${ }^{13}$ ["as a realm of national memory and myth, to install a unified wartime identity in a politically and culturally fractured France. Here the myth was that of French classicism: France was 'Latin' and thus classic in culture, but according to a circumscribed notion of the style that was rooted in the ideology of monarchist Right."]. (Prev. autor). Jane F. Fulcher, The Composer as Intelectual. Music and Ideology in France, 1914-1940, Oxford, Oxford University Press, 2006, 20. Према ауторки, током Првог светског рата и у декади након његовог завршетка, композитори који су припадали конзервативној десници у Француској (следбеници Сезара Франка [César Franck, 1822-1890] или Сен Санса, као што је Денди), заступали су реторику према којој је француска култура у основи латинска (не грчка), самим тим класична, наспрам „“нордијског’ романтизма и ирационалности 'Хуна'“, cf. Jane F. Fulcher, "The Composer as an Intellectual: Ideological Inscriptions in French Interwar Neoclassicism", The Journal of Musicology, Vol. 17, No. 2, University of California Press, 1999, 200. Ова реторика претходила је и формирању „Лиге за одбрану француске музике“ (“League pour la Défence de la Musique Française”), коју је основао Шарл Теронк (Charles Teronc) 1916. године, са циљем да одржи француску музику чистом и ослобођеном од било каквих страних утицаја - највише немачких и аустријских (иако је музика бечког класицизма XVIII века сматрана добрим узором) - што се огледало и у оперском и концертном репертоару тога доба. Cf. Ibid., 203-204. У међувремену, композитори (и/као интелектуалци) повезани са француском левицом (као, у одређеној мери Морис Равел, Ерик Сати [Erik Satie], или „Шесторка”) сматрали су да су класични модели универзални појам који нема везе са расом или националном припадношћу, док су дела која су компоновали оцењивана као истовремено „традиционална“ и „модерна“. Cf. Ibid., 211-212. Постојала су и различита 'сврставања' ових композитора у складу са њиховим односом према левој или десној оријентацији (као рецимо у случају Мориса Равела, на пример), што ћемо у овом тренутку оставити по страни. Такође, коришћење елемената популарне музике и тема из савремене свакодневнице је важно за лево оријентисане композиторе, али овај аспект њиховог стваралаштва би могао да се обради као засебна тема. 
По завршетку Првог светског рата, догодила се промена у значењу термина:

Заступници савремене уметности су тежили да сакрију њене везе са предратним правцима, осим неколико изузетака, које су, на различите начине, посматрали углавном као лоше. За те уметнике и критичаре, Дебиси [Claude Debussy] је био икона импресионизма [...]. Исто тако, Равела [Maurice Ravel] су повезивали са пренаглашеним романтизмом и чињеницом да је Валцер [La Valse] био прво послератно дело које је одговарало таквом опису. ${ }^{14}$

На пример, један од заступника таквих идеја био је Жан Кокто (Jean Cocteau, 18891963), који је хвалио Ерика Сатија (1866-1925): „Кокто је одвојио Сатија од предратних тенденција или удаљених националних традиција. 'Класични' пут ка јасноћи који је Кокто приписивао Сатију био је један од усамљених примера који није залазио у дубоку прошлост. 'Нова једноставност' Сатија [...] је истовремено и 'класична' и 'модерна'; то је била француска музика која се није позивала на било коју другу француску музику“. ${ }^{15}$ Према Коктоу, Сатијева музика је била модернистичка. У најширем смислу, модернистичка својства неокласицизма (у свом новом, послератном значењу) била су, према Месингу, са једне стране, склоност уметника према

стабилном, поновном уласку у водеће токове европске уметности, као и носталгији коју би такав повратак имплицирао. Истовремено, [...] било какав савез са прошлошћу могао је да компромитује креативност и у то време било је мудро остати културно сироче. [....] Термин [неокласицизам] је добио своје ново значење почев од 1923. године, када је повезан са Игором Стравинским, [Игорь Фёдорович Стравинский, 1882-1971] [...] и тај однос се показао као одлучујући у коначном дефинисању значења термина неокласицизам, које је било другачије од оног које је претходно имао. ${ }^{16}$

До сада смо изнели мишљења различитих аутора који су се бавили разноврсним аспектима, у најширем смислу, (нео)класицистичке естетике - или су спомињали, односно индиректно имплицирали ситуацију у којој је настало значење термина, али и културну политику која је у вези са њим, а која се променила након завршетка Првог светског рата. Разлози за такве промене постоје и на колективном и на индивидуалном нивоу, као психолошки, социолошки, економски и тако даље. Пре него што испитамо неке детаље који се тичу естетике неокласицизма и поетика одређених аутора, прећи ћемо на један другачији контекст настанка неокласицизма.

\footnotetext{
${ }^{14}$ ["Some propagandists of contemporary art tended to disavow any kinship with pre-war styles which with few exceptions, they generally regarded as corrupt in one way or another. For these artists and critics, Debussy was the avatar of impressionism [...]. Likewise, Ravel was associated with a gaudy romanticism and the fact that $\mathrm{La}$ valse was his first post-war work that encouraged this assessment."]. (Прев. аутор). Scott Messing, op. cit., 76. 15 ["Cocteau set Satie apart from either pre-war trends or remote national traditions. The 'classical' path of clarity which Cocteau accorded Satie was a solitary one that did not reach into the past. The 'new simplicity' of Satie [...] was both 'classic' and 'modern'; 'a French music' that did not recall any other French music.']. (Прев. аутор). Ibid., 77.

${ }_{16}$ ["stabilizing reentry into the mainstream of European art and a nostalgia for the past which that return implied. Contemporary to that tendency $[\ldots]$ an alliance with the past might compromise creativity and it was wise to remain a cultural orphan. [....] The term [neoclassicism] enjoyed a renewed life begining in 1923 because it was associated with Stravinsky, [...] and that relationship would prove decisive in securing a meaning for neoclassicism that was different from what it once had."]. (Прев. аутор). Ibid., 85.
} 
Остављајући по страни друге европске земље у којима се појавио неокласицизам (као што су Вајмарска република, Совјетски Савез или Италија), испитаћемо услове у којима се неокласицизам појавио у српској музици, имајући у виду не само географску, већ и темпоралну дистанцу.

Неокласицизам се у историји српске музике појавио релативно касно у поређењу са својим француским панданом. Тачније, појавио се педесетих година XX века, као доминантан правац унутар тенденција такозваног умереног модернизма. У међувремену, догодио се још један рат великих размера (Други светски рат), а у Југославији, чији је Србија била саставни део, променило се државно и друштвено уређење (међуратна монархија је постала федерална република коју је предводила Комунистичка партија). То је условило измене у уметности и култури, нарочито ако имамо у виду да се током тридесетих година догодио, „повратак са студија композитора тада најмлађе генерације, припадника 'прашке групе', који домаћа историја бележи као 'први авангардни' удар у српској музици“, ${ }^{17}$ иако је у то време било неколико скромних неокласицистичких доприноса у историји српске музике, отелотворених у стваралаштву, на пример, Предрага Милошевића (1904-1988, такође члана 'прашке групе'). ${ }^{18}$ Након Другог светског рата, „Симплификовани вид музичког неокласицизма у Србији, препознатљив по премисама социјалистичког реализма, био $\mathrm{je,} \mathrm{y} \mathrm{ствари} \mathrm{последица} \mathrm{[његове]} \mathrm{идеолошке} \mathrm{и} \mathrm{политичке} \mathrm{употребе“.}{ }^{19}$ Премисе социјалистичког реализма су у одређеној мери већ и биле присутне у „заокрету ка методи реализма“, ${ }^{20}$ током тридесетих година, али, према Мирјани ВеселиновићХофман,

соцреалистичка теза се у српској музици није испољила у свом најекстремнијем догматском виду [...]. Томе је значајно допринео отворени сукоб тадашњег политичког врха наше земље и Совјетског Савеза обзнањен крајем јуна 1948. [....] Иако су нове политичке прилике у тадашњој Југославији учиниле теоретски могућим чак и напуштање соцреалистичких позиција, уметничко стваралаштво је све до 1951. па и до 1954. године и у Србији било изложено разним видовима идеолошко-политичке контроле. ${ }^{21}$

Будући да је социјалистички реализам постепено бледео током педесетих година, „једини могући модернистички изазов који су српски уметници могли да начине у односу на културу и 'прописане' естетске норме био је умерени модернизам“.22 Такође, умерени модернизам, према речима Весне Микић, означава нерадикални модернизам „као 'кровни' појам српске уметничке музике педесетих година. По нашем мишљењу овај приступ би могао да [...] олакша разумевање веома компликоване терминологије

\footnotetext{
${ }^{17}$ Vesna Mikić, Lica srpske muzike: neoklasicizam, Beograd, Fakultet muzičke umetnsoti, 2009, 106.

${ }^{18}$ Cf. Ibid., 107.

19 Мирјана Веселиновић-Хофман, „Музика у другој половини ХХ века“, у: Мирјана ВеселиновићХофман (ур.), Историја српске музике. Српска музика и европско наслеђе, Београд, Завод за уџбенике, $2007,108$.

${ }^{20}$ Ibid.

${ }^{21}$ Ibid., 108-109.

22 ["the only possible modernistic challenge that Serbian artists could make in relation to the culture and its 'prescribed' aesthetic norms was moderate modernism.”]. (Прев. аутор). Vesna Mikić, „Aspects of (Moderate) Modernism in the Serbian Music of the 1950s“, in: Dejan Despić, Melita Milin (Eds.), Rethinking Musical Modernism, Belgrade, Institute of Musicology, Serbian Academy of Sciences and Arts, 2008, 187-188.
} 
нео/изама“. ${ }^{23}$ Разлози за временску дистанцу од тридесетак година, која се појављује између српског неокласицизма и његовог француског пандана могу да се траже у укупној модерној историји српске уметничке музике, која се развијала у другачијим историјским и социо-политичким условима. Отуд и 'закашњење' у развоју уметничког канона који је тек требало потврдити и надоградити, уместо критиковати, подривати или деконструисати, што је био случај у европској уметности и култури XX века. ${ }^{24}$

До сада је појава неокласицизма у француском или српском/југословенском контексту била централна тема наше дискусије, од генезе самог појма, тренутка у историји у којем се појавио и навођења неких од његових основних одлика. Сада ћемо заћи дубље у неке од естетичких проблема везаних за неокласицизам и испитати два 'продукта' различитих неокласицистичких поетика.

\section{Шта учинити са спутаним емоцијама? (2)}

Када Теодор Адорно (Theodor Adorno) разматра музику Игора Стравинског, он тврди да су њене рестаураторске особине у складу са регресијом у друштву. ${ }^{25}$ Стравински, према томе, покушава да помири музику XVIII века и савремену музику, користећи старе композиционе технике и (испрва) ограничавајући нове композиционе технике према старима, тако креирајући дисонанцу између старог и новог. ${ }^{26}$ Потом, ова дисонанца постаје део индивидуалног музичког језика Игора Стравинског. ${ }^{27}$ Уколико се ове тврдње примене на неокласицизам у целини, није тешко закључити да је Адорнов став према њему негативан у смислу да је неокласицизам (према својим главним особинама, а у односу на друштвено-историјски контекст тог доба) антимодеран. Слично Адорну, за Макиса Соломоса (Макис Соломос), 'позив на ред’ који је Кокто јавно прокламовао 1923. године, стигматизовао је модерност фовизма, експресионизма, кубизма и конструктивизма. ${ }^{28}$

Оставићемо ово гледиште по страни. Постојале су бројне тврдње према којима би повратак било које врсте био сматран некаквим 'процесом излечења'. У Француској, како смо то раније споменули, било је потребно постићи баланс између носталгије за прошлошћу и модерности, наћи такозвани 'средњи пут', какав је заступао Кокто. У Немачкој, то је била Бахова (Johann Sebastian Bach, 1685-1750) музика. ${ }^{29}$ Очигледно да

\footnotetext{
23 ["as a kind of 'umbrella' term of the Serbian music of the 1950s. This kind of approach could possibly, in our opinion: [...] facilitate understanding od very complicated neo/isms terminology.”]. (Прев. аутор). Ibid., 187. Термин умерени модернизам може да се користи и у ширим контекстима, а тиче се трансформације производа авангардних покрета у масовну потрошачку уметност. Ово представља другу тему за истраживање, те ћемо умерени модернизам користити као кровни појам за различите нео/изме.

${ }^{24}$ Више информација у: Vesna Mikić, Neoklasicizam... op. cit., 105-111.

${ }^{25}$ Cf. Theodor W. Adorno, Filozofija nove muzike, Beograd, Nolit, 1968, 219.

${ }^{26}$ Ibid., 222.

27 Ibid.

${ }^{28}$ Cf. Makis Solomos, „Néoclassicisme et postmodernisme : deux antimodernismes“, in: Musurgia, Vol 5, 3/4, 1998, 92, https://www.jstor.org/stable/40591798, ac. 22.02.2019.

29 Више информација у: Walter Frisch, „Bach, Regeneration and Historicist Modernism“ in: German Modernism. Music and the Arts, Berkeley, Los Angeles, London, University of California Press, 2005, $138-185$. Овакве тенденције су довеле до појаве „историцистичког моденизма“ који је своје отелотворење нашао у делима Феруча Бузонија (Ferruccio Busoni, 1866-1924) и Макса Регера (Max Reger, 1873-1916), а које Фриш сматра другачијим од неокласицизма. За разлику од њега, Месинг, дискутујући о музици на
} 
су различити 'процеси лечења' били део „безобзирне активности да се изгради један будући свет“, како смо то навели на почетку овог текста. На који год начин да су савременици, или њихови ближи или даљи следбеници интерпретирали ове тенденције, чини се да су они управо били део пројекта модерности, што је врло јасна одлика модернзма. ${ }^{30}$ Ако свему томе додамо и тврдњу Данијела Олбрајта (Daniel Albright) да модернизам представља „тестирање гранища естетских конструкција“ ${ }^{31}$ модернизам постаје далеко шири концепт. У том смислу, Олбрајт додаје да је „модернизам покрет повезан са строгим избором уметничког материјала, али и напорним радом да се тај материјал уреди. Понекад би модернисти напуштали домен уметничке селекције како би достигли необична стања свести (као транс, сан и тако даље); али, изузев различитих дадаистичких експеримената, они уметничку селекцију никада нису трајно напустили“.32 Ова тврдња нам значајно олакшава посматрање неокласицизма као модернизма.

Иако нису настала из пера композитора француског порекла, дела Игора Стравинског су кључна за дефинисање неокласицистичке естетике међуратног периода, како је то објаснио Месинг. Да ли, према томе, постоје нека 'лековита' својства његове музике? Или, како Стравински премошћава традиционално и модерно, што је, изгледа, био уобичајени поступак композитора у Паризу током двадесетих година? „Стравински је тврдио да се не претвара да компонује музику будућности [...] изјавивши да су 'модернисти уништили модерну музику' током ьујоршког интервјуа из 1925“.33 Решење за оно што је Стравински звао „уништеном модерном музиком“ проналази се у следећој композиторовој изјави: „моја слобода биће утолико већа и дубља уколико уже ограничим своје поље акције и окружим се са више препрека. Оно што ми уклања сметњу, отклања ми снагу“. ${ }^{34}$ Дакле, решење је у самоограничавању у компоновању, које је у складу са Олбрајтовом тврдњом о модернизму. Стога, предочићемо неколико особености балета Аполон (Apollon musagète, 1928).

Једноставност овог балета огледа се већ у његовој оркестрацији. Стравински употребљава редукован гудачки оркестар, од укупно 34 извођача, како је то назначио у партитури. Употребом монохроматског ансамбла, од самог почетка, било која 'неочекивана' промена тембра је онемогућена, самим тим неутрализујући било који елемент изненађења у ушима слушаоца. Ово се потврђује и чињеницом да Стравински

прелому векова у Немачкој, тумачи исте тенденције као неокласицистичке, у најширем смислу. Видети: Scott Messing, ,Neoclassicism in Germany“, in: op. cit., 61-74.

${ }^{30}$ Miško Šuvaković, „Modernizam“, u: Miško Šuvaković, Pojmovnik teorije umetnosti, Beograd, Orion Art, 2012, 448.

31 ["the testing of the limits of aesthetic construction,"]. (Прев. аутор). Daniel Albright, Untwisting the Serpent. Modernism in Music, Literature and other Arts, Chicago and London, The University of Chicago Press, 2000, 29.

32 ["Modernism was a movement associated with scrupulous choice of artistic materials, and with hard work in arranging them. Sometimes the Modernists deflected the domain of artistic selection to unusual states of consciousness (trance, dream, and so forth); but, except for a few dadaist experiments, they didn't abandon artistic selection entirely...”]. (Прев. аутор). Ibid., 31.

${ }^{33}$ ["Stravinsky claimed that he was not pretending to write the music of the future [...] when he argued that 'Modernists have ruined modern music' during an interview in New York in 1925...']. (Прев. аутор). Maurin A. Carr, After the Rite. Stravinsky's Path to Neoclassicism (1914-1925), Oxford - New York, Oxford University Press, 2014, 31.

${ }^{34}$ Igor Stravinski, Moje shvatanje muzike, Beograd, Vuk Karadžić, 1966, 27. 
избегава било какве 'нагле покрете', као што би биле нагле промене динамике, или, извођачке технике, као што би била, на пример, col legno. Можда најзначајнија одлика овог балета, у погледу Стравинскијевих самостално наметнутих препрека, су мелодија и ритам. Ритам балета је у великој мери статичан и мање подложан промени. Самим тим, свака промена метра постоји како би омогућила 'природнији' ток мелодије. Карактеристике мелодије, у поређењу са ритмом, далеко су подложније променама, но те промене су строго контролисане процесом сталног варирања, те је свака промена у мелодијском материјалу увек припремљена, то јест, најчешће је поступна. Музички језик је дијатонски, уз повремене битоналне конфигурације. Све ове процедуре су повезане са Стравинскијевим концептом компоновања по принципу сличности, који је део композиторове интерпретације појма хронономија Пјера Сувчинског (Pierre Suvchinsky) и теорије о онтолошком и психолошком времену. ${ }^{35}$ Све је у складу са радњом инспирисаном грчком митологијом, где су у центру Аполон и три музе, Терпсихора, Полихимнија и Калиопа. Тако Стравински 'лечи' модерну музику ограничавајући сопствене композиционе процедуре које јесу, или би могле да се интерпретирају као класичне, али истовремено, помоћу њих одржавајући сопствену изражајаност, што је објашњено у раније цитираним композиторовим изјавама о поетици. ${ }^{36}$

Премештајући се на другачији контекст, као што смо то учинили у претходном поглављу, дискутоваћемо о једној од композиција можда најзначајнијег неокласицистичког композитора у Београду у периоду након Другог светског рата. Милан Ристић (1908-1982) се афирмисао као неокласичар када се, након кратке паузе у првим годинама након Другог светског рата, вратио на београдску музичку сцену представивши публици своју Другу симфонију (1951). Но, током окупације Југославије, ратна тематика није заобишла Ристићево стваралаштво. То је очигледно у делима као што су Прва симфонија (1941) или симфонијска поема Човек и рат (1943). Према речима Марије Бергамо

Ристић је започео рад на [Првој] симфонији само четири дана после Хитлеровог напада на СССР. У току пет месеци интензивног рада, некој врсти личне реакције на спољашње догађаје, створио је дело напрегнуте динамике, засићено у звуку који у густим, полифоним линијама нараста до избезумљених крикова, потресних вапаја и херојских акцената. ${ }^{37}$

У овом, како га ауторка назива, зрелом експресионистичком периоду, чији врхунац представља Прва симфонија, аутор покушава да „изврши компромис између технике и израза Шенберга и Хиндемита“. ${ }^{38}$ Пре свега, мисли се на доследност у спровођењу

\footnotetext{
${ }^{35}$ Више информација у: Igor Stravinski, op. cit., 16-18; Мирјана Веселиновић-Хофман, Пред музичким делом, Београд, Завод за уџбенике, 2007, 127-128.

36 Важно је напоменути да Стравински, током свог неокласичног периода, тежи рестаурацији композиционо-техничких процедура из прошлости којом је инспирисан. Ово је очигледније у делима која садрже цитирани материјал, где сам материјал имплицира композиционо-техничке процедуре које ће се даље користити. Cf. Mirjana Veselinoivć-Hofman, Fragmenti o muzičkoj postmoderni, Novi Sad, Matica srpska, 1997, 45-46.

${ }^{37}$ Marija Bergamo, Delo kompozitora. Stvaralački put Milana Ristića od Prve do Šeste simfonije, Beograd, Univerzitet umetnosti, 1977, 43.

${ }^{38}$ Ibid., 40.
} 
Шенберговог (Arnold Schoenberg, 1874-1951) „принципа атоналности“, али и никада догматски схваћене и доследно коришћене додекафоније, наспрам којих се налазе Хиндемитови (Paul Hindemith, 1895-1963) композиционо-технички принципи на плану мотивског рада, док је истовремено, у Ристићевом стваралаштву, присутан и ослонац на класичне форме и полифонију. ${ }^{39}$

Разуме се да је након Другог светског рата и промењене друштвено политичке ситуације у земљи Ристић, током поменуте краће паузе у стваралаштву, у време доминације доктрине социјалистичког реализма, спорадично писао и поједина пригодна дела, као што су разне обраде народних песама па чак и неколико мелодрама. Чини се да је управо тада дошло до периода трагања за неком врстом стабилних основа не само у поетици Милана Ристића, или поетикама његових савременика, него и у укупном музичком животу Београда након 1945. године. Односно, „Наступио је нови период противречности и кризе, испуњен лутањима и колебањима, која су постепено претварана у нова, правилнија таласања и чвршће импулсе који су се афирмисали после 1950“.40 Та нова, правилнија таласања и чвршћи импулси се односе на спомињане неокласицистичке тенденције у опусу овог аутора које постају видне у Ристићевим делима насталим током шесте деценије.

Посветивши се писању симфонијске музике (мада је имао и значајан број дела других жанрова), 1957. године компоновао је Симфонијске варијащије. ${ }^{41}$ Пратећи принципе очигледне у поетици Паула Хиндемита, од којих су неке елабориране у композиторовом последњем предавању под називом „Умируће воде“, из 1963. године, Милан Ристић истражује границе и покушава да превазиће (да употребимо Стравинскијев израз) препреке неокласицизма. Наиме, Хиндемит заступа тезу да немодални систем тоталног тоналитета, како назива технику проширене тоналности, где се користи свих дванаест тонова хроматске лествице, представља најпогоднији систем за компоновање музике. ${ }^{42}$ То је уједно и музички језик који користи Ристић у Варијацијама, оркестрираним за симфонијски оркестар двојног састава. Тема за варијације је период од три реченице тонално центриране in В и садржи свих дванаест тонова хроматске лествице. Током девет варијација (од којих је последња фуга), композитор истражује потенцијал теме, стварајући и представљајући њена (некада потпуно) различита 'лица' публици. Уважавајући све принципе развојног варирања (какво се среће код Арнолда Шенберга и његових следбеника), Ристић одржава

\footnotetext{
${ }^{39}$ Cf. ibid., 40-41.

${ }^{40}$ Ibid., 63.

${ }^{41}$ Милан Ристић се, као и његове друге колеге (најпре Љубица Марић [1909-2003] и Станојло Рајичић [1910-2000]) након ране, радикалне модернистичке фазе током тридесетих година, али и суочен са постулатима доктрине социјалистичког реализма након Дугог светског рата, посветио етаблирању умереномодернистичких тенденција у српској музици током педесетих година, одбацивањем идеја социјалисичког реализма (који никада није постао званична доктрина културне политике Југославије). Више информација у: Мирјана Веселиновић-Хофман (ур.), Историја српске... ор. cit., 193-213; Vesna Mikić, Lica srpske... op. cit.

${ }^{42}$ Cf. Paul Hindemith, „Umiruće vode“, u: Vlastimir Peričić et al. (ur.), Zvuk. Jugoslovenska muzička revija, 69, 1966, 453-454. За Хиндемита, сваки композитор који тражи иновацију у организацији тонског материјала није истински иновативан. Такође важно је напоменути да Хиндемит ово тврди у време када су композитори као Карлхајнц Штокхаузен (Karlheinz Stockhausen, 1928-2007), Џон Кејџ (John Cage, 19121992), Кржиштоф Пендерецки (Krzysztof Penderecki, poђ. 1933) и други представници различитих авангардних покрета активни.
} 
интегритет теме, која, као и свака друга тема која би 'доживела' третман варирања, би могла да се распадне у низ одвојено варираних фрагмената. Према томе, ова одлика овог релативно кратког оркестарског комада постаје главна за неокласицистичку рестаурацију „примарних стилских обележја““ класичних варијација. ${ }^{43}$

\section{Закључак}

Циљ овог рада није био да се прикажу директне импликације ратних траума у животима композитора (или људи уопште), или да се преиспитају све друштвенополитичке промене које су се десиле услед великих ратова и које су утицале на културу и уметност, већ да се испитају начини на које су композитори и хроничари музичког живота успостављали стабилност у различитим аспектима културе, уметности или у индивидуалним поетикама. Почев од генезе појма, дефиниције неокласицизма и неокласичног су се мењале кроз историју. Значење се мењало и у складу са (не)могућим рестаурацијама или оживљавањима различитих музичких прошлости и различитим начинима њихове интерпретације. Са једне стране, могуће је применити методологију стила како би се означиле одлике неокласицизма (али и било ког другог правца прве половине XX века, као што је рецимо, експресионизам), а са друге (погодније) стране, имајући у виду да се бавимо дефинисањем уметничког правца, неокласицизам се дефинише или разумева под 'капом' умереног модернизма. Сагледавши његове одлике, можемо и даље дебатовати о томе да ли је неокласицизам модернизам или није. Пре него што, или уместо што закључимо нешто по том питању, понудићемо троделну формулу, према којој разумемо одлике неокласицизма.

Поглед према (музичкој) прошлости (не било којој, већ оној која је постала традиција), како би се поново успоставила стабилност у било ком пољу музичког живота (по могућству након колективне ратне трауме), од индивидуалних поетика до укупне културне политике би био први део. Ово је заједничка одлика различитих неокласицистичких композитора, упркос чињеници да су они, у различитим опусима, тражили различите начине за ревитализацију традиције, али и често демонстрирали немогућност њене ревитализације. Други корак би се односио на поменути процес рестаурације примарних стилских обележја, или, на увођење традиције у савремени контекст. ${ }^{44}$ Трећи део би био комбинација прва два. Будући да свака традиција намеће и сопствена правила, она потом постају основа за самоограничавање у поетици одређеног аутора. Упркос томе, та ограничења постају управо поље у којем композитор демонстрира сопствене композиторске вештине. Другим речима, музика за безобзирно креирање будућег света Гостушког, постаје - било да се композитори слажу са концептом 'музике за будућност' или не - иновација у ограничавању.

\footnotetext{
43 О неокласицистичкој рестаурацији „примарних стилских обележја“ видети: Mirjana VeselinovićHofman, Fragmenti... op. cit., 30.

${ }^{44}$ Више информација у: Miško Šuvaković, op. cit., 449.
} 


\section{Цитирана дела}

Adorno, Theodor W.: Filozofija nove muzike, (prev. Ivan Focht). Beograd: Nolit, 1968.

Albright, Daniel: Untwisting the Serpent. Modernism in Music, Literature and other Arts, Chicago and London: The University of Chicago Press, 2000.

Bergamo, Marija: Delo kompozitora. Stvaralački put Milana Ristića od Prve do Šeste simfonije. Beograd: Univerzitet umetnosti, 1977.

Carr, Maurin A.: After the Rite. Stravinsky's Path to Neoclassicism (1914-1925). Oxford New York: Oxford University Press, 2014.

Frisch, Walter: Bach, Regeneration and Historicist Modernism“ in: German Modernism. Music and the Arts. Berkeley, Los Angeles: London, University of California Press, 2005, $138-185$.

Fulcher, Jane F.: „The Composer as an Intellectual: Ideological Inscriptions in French Interwar Neoclassicism“, The Journal of Musicology, Vol. 17, 2, 1999, 197-230.

Fulcher, Jane F.: The Composer as Intelectual. Music and Ideology in France, 1914-1940. Oxford: Oxford University Press, 2006.

Gostuški, Dragutin: Vreme umetnosti. Beograd: Prosveta, 1968.

Hindemith, Paul: „Umiruće vode“, (prev. Marija Koren), u: Vlastimir Peričić et al. (ur.), Zvuk. Jugoslovenska muzička revija, 69, 1966, 455-458.

Kovačević, Krešimir (ur.): Muzička enciklopedija. Zagreb: Jugoslovenski leksikografski zavod, 1974.

Medić, Ivana:“Alfred Schnittke's Operas from the 1990s in the Context of Trauma Studies“, in: Sonja Marinković et al. (Eds.), Challenges in Contemporary Musicology. Belgrade: Faculty of Music, 2018, 247-259.

Messing, Scott: Neoclassicism in Music. From the Genesis of the Concept through the Schoenberg/Stravinsky Polemic.Rochester: University of Rochester Press, 1996.

Mikić, Vesna: "Aspects of (Moderate) Modernism in the Serbian Music of the 1950s", in: Dejan Despić, Melita Milin (Eds.), Rethinking Musical Modernism. Belgrade: Institute of Musicology, Serbian Academy of Sciences and Arts, 2008, 187-193.

Mikić, Vesna: Lica srpske muzike: neoklasicizam. Beograd: Fakultet muzičke umetnosti, 2009.

Solomos, Makis: „Néoclassicisme et postmodernisme : deux antimodernismes“, in: Musurgia, Vol 5, No. 3/4, 1998, 91-107, https://www.jstor.org/stable/40591798, ac. 22.02.2019.

Stravinski, Igor: Moje shvatanje muzike. Beograd: Vuk Karadžić, 1966.

Šuvaković, Miško: Pojmovnik teorije umetnosti.Beograd: Orion Art, 2012.

Veselinoivć-Hofman, Mirjana: Fragmenti o muzičkoj postmoderni. Novi Sad: Matica srpska, 1997. 
Веселиновић-Хофман, Мирјана: „Музика у другој половини XX века“, у: Мирјана Веселиновић-Хофман (ур.), Историја српске музике. Српска музика и европско наслеђе.Београд: Завод за уџбенике, 2007, 107-135.

Веселиновић-Хофман, Мирјана: Пред музичким делом. Београд: Завод за уџбенике, 2007.

Микић, Весна: „Неокласичне тенденције“, у: Мирјана Веселиновић-Хофман (ур.), Историја српске музике. Српска музика и европско наслеђе, Београд: Завод за уџбенике, 2007, 193-213.

\section{Сажетак}

Завршивши се пре сто година, Први светски рат, догађај колосалних пропорција, променио је, како европску, тако и светску историју, те је вероватно, у наредним годинама (односно, двадесетим годинама XX века), узроковао велики број ‘позива на ред’, да парафразирамо наслов познатог есеја Жана Коктоа (Jean Cocteau) из 1923. године. Стога смо у најопштијим цртама, изложили неке од друштвено-историјских услова настанка неокласицизма у Паризу, убрзо након Великог рата. Имајући то у виду, испитали смо опште услове појаве неокласицизма у српској музици, који се (уважавајући неколико скромних покушаја у међуратном периоду) појавио као (донекле) доминантан покрет касније у односу на свој француски пандан, то јест, педесетих година XX века. Тренутно је једина уочљива корелација између два неокласицизма та да се и један и други појављују након значајних, примарно деструктивних историјских догађаја. Препознајући да су се у моменту након завршетка великих ратова контексти мењали, истраживали смо начине на које су композитори (у нашем случају Игор Стравински [Игорь Фёдорович Стравинский] и Милан Ристић) покушавали да пронађу стабилан пут ка главним токовима развоја уметности и да, у одређеној мери, редефинишу своје поетике. 